\title{
Soft Power: A Driver of the Rise of the Treasury of a Language
}

\author{
Mahmoud Altalouli \\ English for International Students, Duke University, Durham, USA \\ Email: mahmoud.altalouli@duke.edu
}

How to cite this paper: Altalouli, M. (2021). Soft Power: A Driver of the Rise of the Treasury of a Language. Open Journal of Modern Linguistics, 11, 668-671.

https://doi.org/10.4236/ojml.2021.114052

Received: November 19, 2020

Accepted: August 21, 2021

Published: August 24, 2021

Copyright (c) 2021 by author(s) and Scientific Research Publishing Inc. This work is licensed under the Creative Commons Attribution International License (CC BY 4.0).

http://creativecommons.org/licenses/by/4.0/

\begin{abstract}
This paper argues that through soft power techniques including cultural missions and education exchange programs, the treasury of language expands. Speakers of a language deposit a number of language aspects such as grammar, vocabulary, and pronunciation into the treasury of that language. If an expanded treasury is a concern, soft power techniques should be adopted. The English language treasury has been in the rise as a result of cultural missions and education exchange programs, namely run by the British Council and AMIDEAST.
\end{abstract}

\section{Keywords}

Globalization, Soft Power, Economic Colonialism, Linguistic Imperialism

\section{Introduction}

Human language is a tremendous asset for everyday social interactions. It is well described by Saussure (1966: p. 30) as a "treasury" shared by all members of a community. In fact, different community members can deposit into the "treasury"; such deposits include pronunciation, vocabulary and grammar. Speakers of the English language, for example, can deposit into their treasure new sounds, words, phrases, and sentence structures. English is spoken by about 1.1 billion first and additional language speakers around the world, of whom about $34 \%$ are "native" speakers (Eberhard et al., 2020). While Mandarin Chinese is the most spoken language by only first language (native) speakers, English is the most spoken language by about 750 million additional language speakers (Eberhard et al., 2020). The number of English speakers may keep on growing, thus the treasury yields rise again. The power behind the expansion of the English language is the focus of this commentary. 
To spread a language in a globalizing world, the power of culture has to come into play. One definition of power is as "the ability to influence the behavior of others to get a desired outcome" (Nye, 2004: p. 2). Power has often been associated with military power. Yet, there is a second face of power, the "econocultural" model (Quirk, 1991). The former can be referred to as "hard power" and is a coercive way to influence the values, attitudes, and interests of other nations. The latter represents the power of culture and language and may be known as "soft power." However, both types of power seem to have political goals-that is, both are forms of political power, though the second is not generally as readily acknowledged. This paper critically examines the two faces of power in terms of their persistent impact on the rise of the English language around the world.

\section{Hard Power and the Spread of English}

Hard power was used as a means to spread the colonizing nation's language, which became a pervasive legacy of colonialism. For instance, in former French colonies such as Senegal and Niger, the official language is French, which seems to be the linguistic inheritance from the colonial period (Salhi, 2013). In fact, French is the main language of education in these and many other former colonial societies in Africa.

Similarly, the spread of English initially resulted from British colonialism. Some colonized countries, including India and Nigeria, have adopted English as their official language. Bhatt (2001), in his overview of the theoretical and power related issues of World Englishes, emphasizes that the spread of English was a result of two diasporas-English being found in countries such as Britain and the United States, where English is the first language and being transported to Asia, Africa, and Latin America. During colonialism of the second diaspora, New Englishes developed and became official in many colonized countries, such as Kenya and Ghana.

However, the first diaspora where English was transplanted by native speakers does not provide sufficient rationale to lead English to become a major world language. According to the concentric circles model of Kachru (1992), the inner circle includes countries including the United States, Canada, Australia, and New Zealand, where English is the native language. Because these countries were all British colonies, English, the language of British Empire, became "simply an extension from the old 'ancestral home' of English to the newer native varieties" (Seidlhofer, 2009: p. 237). After British colonialism, it was the emergence of the new superpower, the United States by the end of the 19th century which made it possible for English to become a global language.

\section{Soft Power and the Spread of English}

While military power was responsible for the original spread of the English language, hard power is no longer the major influence on the expansion of language; the global spread of English is rather part of "neocolonial exploitation" (Penny- 
cook, 2017: p. 326). Even though the military may not be responsible for the spread of English currently, English continues to spread as a result of economic colonialism (Pennycook, 2007). In other words, it is through soft power that the English language continues to grow. The United States, as a superpower in political leadership, uses English to influence its values, interests and certainly language. Using soft power seems to be a post-colonial activity that legitimizes the promotion of a nation's cultural values and language. However, the legitimate language "imposes itself on the whole population" (Bourdieu, 1991: p. 45) against which other languages or varieties of a language must be measured.

Soft power activities are facilitated by the processes of globalization, which are reflected in language use. Linguistic globalization, described as a "historically continuous and rather unexceptional process," (Coupland, 2010: p. 10) is currently closely associated with the spread of English. The current soft power means of expanding English is best exemplified in cultural missions and education exchange programs, not to mention made-in-America innovations including technical devices that use English words as in Internet websites. English Language Teaching programs administered by Britain and U.S. agencies, such as British Council and AMIDEAST respectively, are a result of soft power. In his theory of linguistic imperialism, Phillipson (2000) argues that such educational agencies practice linguistic coercion to enforce their varieties of English. Currently, for example, learners of English in many Middle East and North African countries voluntarily register for English courses at AMIDEAST, where they learn American English. These courses are part of the socio-economic domination of English (Phillipson, 2000).

In essence, English Language Teaching programs can be seen as an activity of Quirk's "econocultural” model, in which English spreads for economic and cultural reasons. An economic reason can be readily seen at educational institutes that earn profits as a result of the high enrollment of English learners. In the realm of cultural exchange, programs offered such as the English Access Microscholarship Program, run by AMIDEAST and funded by the U.S. Department of State, aim to teach American English and U.S. culture and society to students in grades eight and nine (AMIDEAST, 2020). The high enrollment in such classes asserts what Chew (2010) states, "people will be driven to the language or LF (lingua franca) with the most economic and cultural rewards" (p. 57). That is, cultural and economic tools are resources of soft power that can be used to increase the number of speakers of the language used to promote that culture and economy.

\section{Conclusion}

The spread of any world language can happen as a result of a soft power used by a nation that persuades, not imposes, its values and attitudes. The currency of such a power is economic and cultural (Bourdieu, 1991). English is an example of a global language that is widespread as a result of the current status of its main native speaking country: The United States. There is likely to be an increase of 
English speaking individuals and nations as long as the United States maintains its economic superiority and cultural exportation. The country's economy and cultural hegemony would affect how long the treasury of language will last and spread.

\section{Conflicts of Interest}

The author declares no conflicts of interest regarding the publication of this paper.

\section{References}

AMIDEAST (2020). English Access Microscholarship Program. https://www.amideast.org/our-work/find-a-scholarship/high-school-and-younger/engl ish-access-microscholarship-access-program

Bhatt, R. M. (2001). World Englishes. Annual Review of Anthropology, 30, 527-550. https://doi.org/10.1146/annurev.anthro.30.1.527

Bourdieu, P. (1991). Language and Symbolic Power. Harvard University Press.

Chew, P. G. (2010). From Chaos to Order: Language Change, Lingua Francas, and World Englishes. In M. Saxena, \& T. Omoniyi (Eds.), Contending with Globalization in World Englishes (pp. 45-71). Multilingual Matters. https://doi.org/10.21832/9781847692764-006

Coupland, N. (2010). Introduction: Sociolinguistics in the Global Era. In N. Coupland (Ed.), The Handbook of Sociolinguistic and Globalization (pp. 1-27). Wiley-Blackwell. https://doi.org/10.1002/9781444324068.ch

Eberhard, D. M., Simons, G. F., \&Fennig, C. D. (2020.). Ethnologue: Languages of the World (23rd ed.). SIL International.

https://www.ethnologue.com/guides/most-spoken-languages

Kachru, B. (1992). World Englishes: Approaches, Issues and Resources. Language Teaching, 25, 1-14. https://doi.org/10.1017/S0261444800006583

Nye, J. S. (2004). Soft Power: The Means to Success in World Politics. Public Affairs.

Pennycook, A. (2007). ELT and Colonialism. In J. Cummins, \& C. Davison (Eds.), International Handbook of English Language Teaching (pp. 13-24). Springer. https://doi.org/10.1007/978-0-387-46301-8 2

Pennycook, A. (2017). The Cultural Politics of English as an International Language. Taylor \& Francis. https://doi.org/10.4324/9781315225593

Phillipson, R. (2000). English in the New World Order: Variations on a Theme of Linguistic Imperialism and "World" English. In T. Ricento (Ed.), Ideology, Politics and Language Policies: Focus on English (pp. 87-106). John Benjamins.

Quirk, R. (1991). The Question of Standard in the International Use of English. In M. L. Tickoo (Ed.), Languages and Standards: Issues, Attitudes, Case Studies (pp. 153-164). RELC.

Salhi, K. (2013). The Colonial Legacy of French and Subsequent Postcolonial Policy. European Journal of Language Policy, 5, 187-224. https://doi.org/10.3828/ejlp.2013.9

Saussure, F. de. (1966). Course in General Linguistics (W. Baskin, Trans.). McGraw-Hill.

Seidlhofer, B. (2009). Common Ground and Different Realities: World Englishes and English as a Lingua Franca. World Englishes, 28, 236-245.

https://doi.org/10.1111/j.1467-971X.2009.01592.x 